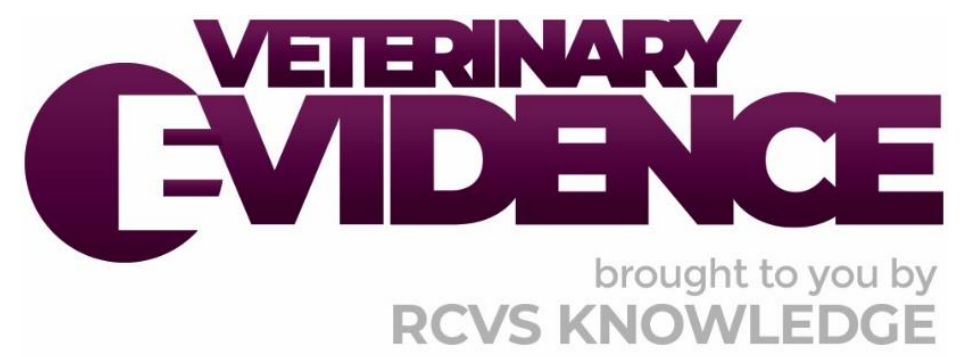

\title{
The use of metronidazole in adult dogs with acute onset, uncomplicated, diarrhoea
}

A Knowledge Summary by

Emma Rogers-Smith BSc(Hons) BA VetMB MRCVS ${ }^{1 *}$

\footnotetext{
${ }^{1}$ Davies Veterinary Specialists, Manor Farm Business Park, Higham Gobion, Hitchin SG5 3HR

*Corresponding Author (Emma.Rogers-Smith@cantab.net)
}

ISSN: 2396-9776

Published: 22 Dec 2021

in: The Veterinary Evidence journal Vol 6, Issue 4

DOI: https://doi.org/10.18849/ve.v6i4.445

Reviewed by: Jennifer Garcia (DVM DACVIM) and Adam Swallow (BVSc MRCVS) 


\section{KNOWLEDGE SUMMARY}

\section{PICO question}

In adult, non-geriatric, dogs with acute onset ( $<7$ days duration) uncomplicated diarrhoea does the addition of metronidazole to a supportive care protocol such as dietary modification or probiotics (excluding other antimicrobials) reduce the time to resolution of diarrhoea compared to supportive care protocols alone?

\section{Clinical bottom line}

\section{Category of research question}

Treatment

\section{The number and type of study designs reviewed}

Four studies were included in this appraisal. Two prospective, double blinded, placebo controlled clinical trials, one prospective treatment trial and one retrospective longitudinal observational study

\section{Strength of evidence}

Weak

\section{Outcomes reported}

One study found a shortened duration of clinical signs (by 1.5 days; $p=0.04$ ) in the metronidazole treated group compared to control. However, a separate study found no significant difference between control and metronidazole groups in the regards to resolution of clinical signs.

One study demonstrated a long standing ( $>28$ day) negative impact of metronidazole treatment on gut microbiome with no difference in time to resolution of clinical signs when compared with faecal matter transplant

\section{Conclusion}

The current evidence for the superiority of metronidazole compared to supportive treatment alone is weak and at this time there is no evidence-based rationale for its use in cases of uncomplicated, acute, canine diarrhoea. Furthermore, the negative implications of metronidazole on the intestinal microbiome have been found to be long standing ( $>28$ days as a minimum) and should not be discounted by the prescribing clinician

\section{How to apply this evidence in practice}

The application of evidence into practice should take into account multiple factors, not limited to: individual clinical expertise, patient's circumstances and owners' values, country, location or clinic where you work, the individual case in front of you, the availability of therapies and resources.

Knowledge Summaries are a resource to help reinforce or inform decision making. They do not override the responsibility or judgement of the practitioner to do what is best for the animal in their care.

\section{Clinical Scenario}

You are presented with an 18 month old female neutered Labrador Retriever with a 3 day history of mixed bowel diarrhoea which includes a small amount of fresh blood following an episode of dietary indiscretion. The patient is up-to-date with routine vaccination and anthelmintic treatment. The dog is bright and your physical examination is completely unremarkable. You wish to provide treatment for this patient and the client is 
requesting metronidazole treatment as this helped 'to clear things up quickly' the last time the patient raided the bins.

\section{The evidence}

Until as recently as 2019 the evidence basis for the use of metronidazole in the face of uncomplicated acute canine diarrhoea (UACD) and its superiority to supportive treatment alone (dietary modification, probiotics and more recently faecal matter transplant) has been anecdotal. Four papers were found to be fully or partially relevant to the PICO question; two randomised, double blinded placebo-controlled trials (Shmalberg et al., 2019; and Langlois et al., 2020), one prospective controlled treatment trial (Chaitman et al., 2020) and one retrospective observational study (Singleton et al., 2019). All four studies measured time to resolution of diarrhoea. Other factors considered included faecal microbiome and metabolome diversity (Chaitman et al, 2020). The evidence for the PICO question was found to be weak and at this time there is insufficient evidence to suggest metronidazole is superior in reducing the duration of clinical signs of UACD when compared to supportive measures alone.

\section{Summary of the evidence}

\section{Shmalberg et al. (2019)}

\begin{tabular}{|c|c|}
\hline Population: & $\begin{array}{l}\text { Client owned dogs presenting to two emergency centres (run by a } \\
\text { university teaching hospital in the USA) for acute diarrhoea (<7 days } \\
\text { duration) with or without concurrent vomiting between March } 2017 \\
\text { and August } 2018 \text {. } \\
\text { Exclusion criteria: large volume haematochezia, clinical signs } \\
\text { compatible with pancreatitis, dogs with high faecal worm egg } \\
\text { counts, clinically relevant comorbidities (endocrinopathies, organ } \\
\text { dysfunction). }\end{array}$ \\
\hline Sample size: & $\begin{array}{l}63 \text { dogs enrolled, } 60 \text { completed the study. Three dogs were } \\
\text { withdrawn and not included in the final analysis due to either a } \\
\text { significant parasite burden ( } n=1 \text {, metronidazole group) or failure of } \\
\text { owners to give the assigned study treatment ( } n=2 \text {, one each in } \\
\text { probiotic and placebo group). }\end{array}$ \\
\hline Intervention details: & $\begin{array}{l}\text { All enrolled dogs had haematology and biochemistry performed in } \\
\text { addition to faecal flotation, commercial gastrointestinal (GI) tract } \\
\text { polymerase chain reaction (PCR) panel (Campylobacter coli, } \\
\text { Campylobacter jejuni, Canine distemper virus, Canine enteric } \\
\text { coronavirus, Canine parvovirus 2, Clostridium dificile Toxin A/B, } \\
\text { Clostridium perfringens alpha and enterotoxins, Cryptosporidium } \\
\text { spp., Giardia spp. and Salmonella spp.) } \\
\text { Three treatment groups. All treatments administered twice daily for } \\
10 \text { days. } \\
\text { - Probiotic Group: Commercial probiotic (Vital Vet, Vital } \\
\text { Planet }{ }^{\circledR} \text { ). } \\
\text { - Metronidazole Group: Metronidazole: } 125 \mathrm{mg} \text { to dogs } 4-10 \\
\text { kg; } 250 \text { mg to dogs between } 10.1 \text { kg and } 20 \text { kg and } 400 \mathrm{mg} \\
\text { for dogs } 20.1-40 \mathrm{~kg} \text {. (Mean metronidazole dose } 17.8 \mathrm{mg} / \mathrm{kg} \text {; } \\
\text { range } 11.2-24 \text { mg/kg). } \\
\text { Placebo Group: Placebo controlled with sucrose at equal } \\
\text { volume to probiotic or metronidazole. } \\
\text { Clinicians were permitted at their own discretion to administer } \\
\text { intravenous fluids (subcutaneous [SQ] or intravenous [IV]), } \\
\text { fenbendazole and/or maropitant. }\end{array}$ \\
\hline
\end{tabular}




\begin{tabular}{|c|c|}
\hline & $\begin{array}{l}\text { Patients were enrolled until there were } 20 \text { cases present in each } \\
\text { group based on prestudy power calculations. } \\
\text { Clients were requested to fast the patient for } 24 \text { hours before a } \\
\text { gradual reintroduction of food over next } 24 \text { hours. } \\
\text { Patients were randomised to a treatment group via pre-study } \\
\text { randomisation schedule. Both the owner and clinician were blinded } \\
\text { to treatment administered. }\end{array}$ \\
\hline Study design: & $\begin{array}{l}\text { Randomised, double-blinded, placebo-controlled clinical trial. } \\
\text { The study was unblinded after enrolment of the } 60 \text { dogs to perform } \\
\text { statistical analysis. }\end{array}$ \\
\hline Outcome studied: & $\begin{array}{l}\text { Time to normal faeces with assessment of faecal consistency, faecal } \\
\text { score (based on the WALTHAM }{ }^{\mathrm{TM}} \text { Faeces Scoring System), } \\
\text { defaecation frequency, straining. }\end{array}$ \\
\hline $\begin{array}{l}\text { Main findings: } \\
\text { (relevant to PICO question): }\end{array}$ & $\begin{array}{l}\text { Dogs were withdrawn from the study due to owner non-compliance, } \\
\text { abnormalities noted on post-enrollment laboratory or PCR testing or } \\
\text { high faecal worm egg count (total withdrawn }=3 \text { ) } \\
\text { Patient age: } \\
\text { - Probiotic group: } 5.3 \pm 3.2 \text { years; } \\
\text { - Metronidazole group: } 5.7 \pm 3.7 \text { years; } \\
\text { - Placebo group: } 5.7 \pm 3.9 \text { years. } \\
\text { There was no statistically significant improvement in time to clinical } \\
\text { resolution of the clinical signs in any treatment group ( } p=0.17 \text { ). } \\
\text { Time to normal faecal consistency: } \\
\text { - Probiotic group: } 3.5 \pm 2.2 \text { days; } \\
\text { - Metronidazole group: } 4.6 \pm 2 \text { days; } \\
\text { - Placebo group: } 4.8 \pm 2.9 \text { days. } \\
\text { No adverse effects were observed in any treatment group. } \\
\text { No dog required rescue treatment. }\end{array}$ \\
\hline Limitations: & $\begin{array}{l}\text { - No standardised treatment protocol so likely multiple } \\
\text { confounding effects between cases, although study design } \\
\text { and statistical analysis has been structured to minimise this } \\
\text { effect. } \\
\text { - Clients were provided a financial incentive which may } \\
\text { influence their interpretation. } \\
\text { - Low case numbers in each treatment group, although the } \\
\text { treatment group sizes were based on pre-study power } \\
\text { calculations. } \\
\text { - No control of diet. } \\
\text { - No microbiome or metabolome testing. }\end{array}$ \\
\hline
\end{tabular}

Singleton et al. (2019)

Population: Analysis of electronic health records from 179 volunteer veterinary practices in the UK that participate in the Small Animal Veterinary Surveillance Network. Cases booked in from 1 April 2014 to 31 January 2017, included all canine consultations that had been classified as 'gastroenteritis' as the main presenting complaint that also had a completed questionnaire pertaining to clinical signs, diagnostics and advice to the client. 


\begin{tabular}{|c|c|}
\hline & $\begin{array}{l}\text { Inclusion criteria: acute, first presentation diarrhoea of }<2 \text { days } \\
\text { duration. } \\
\text { Exclusion criteria: euthanasia on presentation }(n=6) \text { and lost to } \\
\text { follow-up }(n=754) \text {. }\end{array}$ \\
\hline Sample size: & $\begin{array}{l}\text { Initial review of medical records found a total of } 12,455 \text { cases of } \\
\text { 'gastroenteritis' that also included the augmented questionnaire. Of } \\
\text { those 3,192 were found to fit the above inclusion criteria. A further } \\
\text { three cases were excluded due to inaccurate date of birth entry. Of } \\
\text { those 3,189 a further } 760 \text { were excluded for aforementioned } \\
\text { reasons leaving a total of 2,429 cases used within the modelling } \\
\text { dataset. }\end{array}$ \\
\hline Intervention details: & $\begin{array}{l}\text { Information collated on: } \\
\text { - } \quad \text { patient: age, sex, breed, vaccine history, body temperature; } \\
\text { interventions classified as: antimicrobials, anti- } \\
\text { inflammatories, gastrointestinal agents (antacids, } \\
\text { gastroprotectants, antiemetics, anthelmintics) euthanasia } \\
\text { agents; gastrointestinal nutraceuticals (products not listed as } \\
\text { authorised veterinary or human medicines e.g. } \\
\text { pro/prebiotics, kaolin, etc.). }\end{array}$ \\
\hline Study design: & Retrospective longitudinal observational study. \\
\hline Outcome studied: & $\begin{array}{l}\text { Cases considered as resolved if they did not return to the practice } \\
\text { for a 'gastrointestinal' reason between 11-30 days of initial } \\
\text { presentation. Any case re-presenting within } 10 \text { days of initial } \\
\text { presentation was manually checked to ensure no mention of } \\
\text { diarrhoea in case notes. }\end{array}$ \\
\hline $\begin{array}{l}\text { Main findings: } \\
\text { (relevant to PICO question): }\end{array}$ & 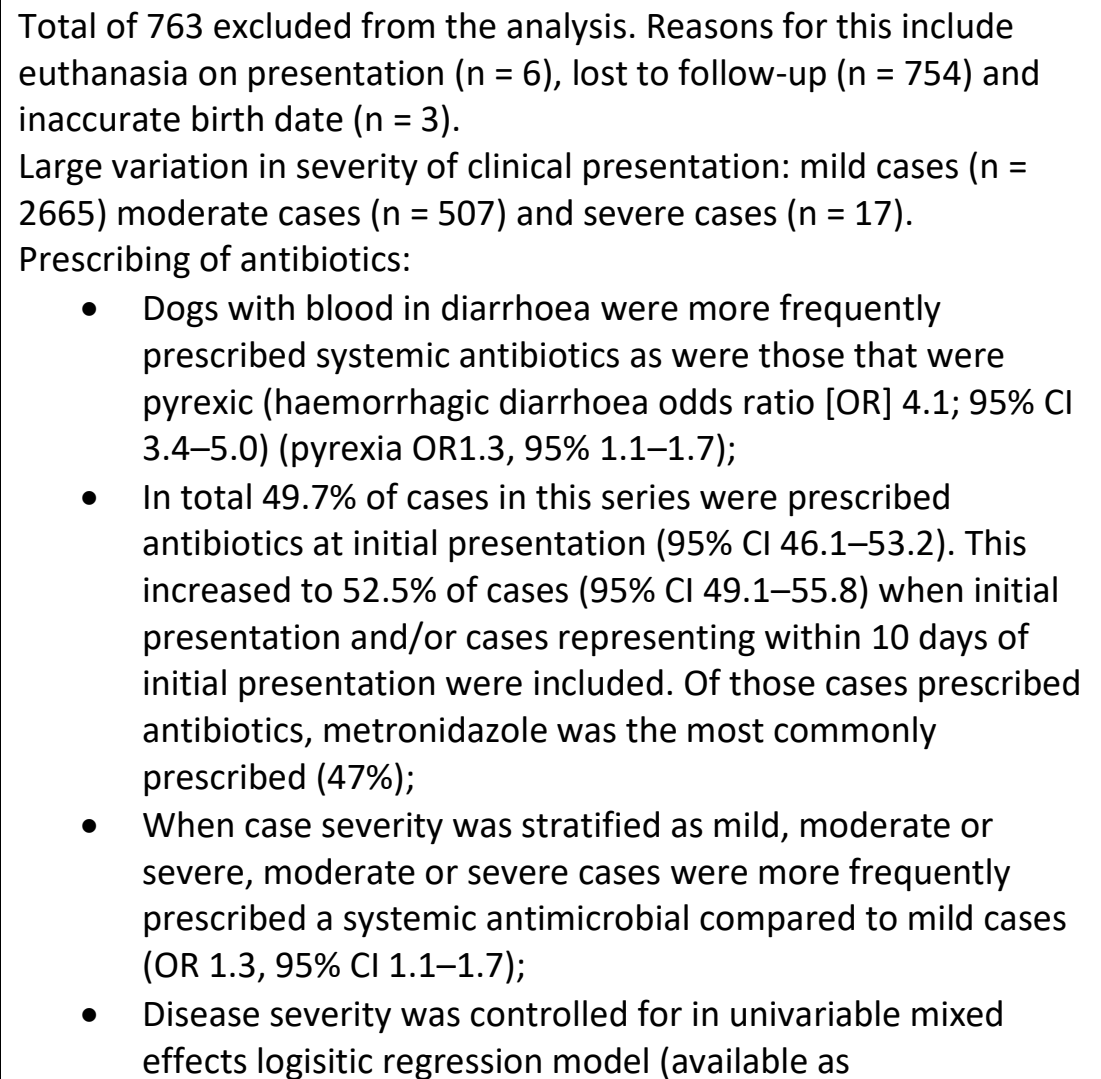 \\
\hline
\end{tabular}




\begin{tabular}{|c|c|}
\hline & $\begin{array}{l}\text { supplementary data in Singleton, et al. [2019]) and was not } \\
\text { significant when considering day } 10 \text { resolution ( } p=0.95) \text {. } \\
\text { Resolution of clinical signs within } 30 \text { days of initial presentation: } \\
\text { - Dietary modification advice and gastrointestinal } \\
\text { nutraceuticals were positively associated with resolution of } \\
\text { signs (OR } 2.8,95 \% \mathrm{Cl} 1.3-6.1) \\
\text { - No such association was found for pharmaceutical agents } \\
\text { including antibiotics. }\end{array}$ \\
\hline Limitations: & $\begin{array}{l}\text { - Retrospective study - limitations of retrospective studies are } \\
\text { extensive but include lack of control for confounding } \\
\text { variables, ability to only infer association not causation, } \\
\text { misclassification bias, convenience recruitment which can } \\
\text { lead to population not being representative of general } \\
\text { population amongst others. } \\
\text { - Calculation of percentage antibiotic prescribing events not } \\
\text { expressly documented within the paper. } \\
\text { - Lack of complete clinical records (for example inconsistent } \\
\text { body temperature recording) for all cases. } \\
\text { - Large loss to follow-up although this may be associated with } \\
\text { a positive outcome (i.e. case does not return to the practice } \\
\text { as clinical signs have resolved) this represents an assumption } \\
\text { and as such definitive positive or negative associations may } \\
\text { be over or under represented. } \\
\text { - Assumption of resolution of clinical signs based on lack of } \\
\text { follow-up appointment. } \\
\text { Lack of standardisation: wide variety of treatments } \\
\text { administered leading to potential for significant confounding } \\
\text { effects. }\end{array}$ \\
\hline
\end{tabular}

Chaitman et al. (2020)

\begin{tabular}{|c|l|}
\hline Population: & 18 client owned dogs presenting between October 2016 and June \\
& 2017 to a specialist practice in New York City with acute diarrhoea \\
(lasting under 14 days). Dogs in acute diarrhoea treatment group \\
may or may not have had concurrent vomiting. \\
Exclusion criteria: pyrexia, tachycardia, tachypnoea, poor general \\
condition, those requiring hospitalisation, known intestinal \\
parasitism, chronic Gl history, pretreatment with antibiotics, drugs \\
that may have precipitated condition (i.e. NSAIDs, corticosteroids) \\
within 2 weeks of presentation. \\
Control population were privately owned living in the same \\
geographical area. Samples were collected as part of a wider study. \\
None of these controls had a history of gastrointestinal signs.
\end{tabular}




\begin{tabular}{|c|c|}
\hline & $\begin{array}{l}\text { FMT: } 10 \text { dogs received a single FMT with } 5 \mathrm{~g} \text { frozen donor stool/kg } \\
\text { BWT. The remaining dog (due to size and availability of donor } \\
\text { faeces) received } 2.5 \mathrm{~g} / \mathrm{kg} \text {. FMT performed by rectal enema and } \\
\text { animals were not fed for } 4-6 \text { hours following enema to reduce risk } \\
\text { of bowel movement. } \\
\text { MET: } 15 \mathrm{mg} / \mathrm{kg} \text { metronidazole give per os every } 12 \text { hours for } 7 \text { days. } \\
\text { Additional treatment included the use of maropitant (Cerenia }{ }^{\circledR} \text {, } \\
\text { Zoetis), } 1 \mathrm{mg} / \mathrm{kg} \text { SQ q24 hours in cases that were vomiting. } \\
\text { Diet was not standardised. } \\
\text { No other treatments were given. } \\
\text { Faecal samples were collected from control dogs at a single time } \\
\text { point as part of a wider study evaluating faecal microbiota across } \\
\text { different locations. }\end{array}$ \\
\hline Study design: & Prospective treatment trial. \\
\hline Outcome studied: & $\begin{array}{l}\text { Evaluation of clinical signs: by assessment of faecal consistency by a } \\
\text { board certified clinician using Purina }{ }^{\circledR} \text { Faecal Scoring Chart on days } \\
0,7 \text { and } 28 \text { (lower score represents a normal stool consistency). } \\
\text { Analysis of faecal microbiota: assess by use of quantitative PCR, } \\
\text { (qPCR) dysbiosis index and } 16 \text { s ribosomal RNA (rRNA) Gene } \\
\text { sequencing. } \\
\text { Analysis of faecal metabolome: measurement of unconjugated bile } \\
\text { acids and untargeted metabolomics approach. }\end{array}$ \\
\hline $\begin{array}{l}\text { Main findings: } \\
\text { (relevant to PICO question): }\end{array}$ & $\begin{array}{l}\text { Faecal scores: } \\
\text { - Faecal scores decreased significantly from day } 0 \text { to day } 7 \text { and } \\
\text { day } 28 \text { in both treatment groups ( } p<0.01 \text { in both cases). } \\
\text { Faecal scores significantly lower in FMT group when } \\
\text { Faecal dysbiosis index (DI): } \\
\text { - No significant difference between treatment groups on day } \\
\text { 0. Significant difference between acute diarrhoea dogs } \\
\text { compared to healthy controls (higher DI in acute diarrhoea } \\
\text { group; } p<0.001 \text { ). } \\
\text { - Dogs after FMT showed significant decrease in DI ( } p<0.05 \text { ). } \\
\text { - Dogs in MET group showed significant increase in DI ( } p \\
\text { - } 0.05 \text { ). } \\
\text { Abundance of Faecalibacteria (associated with health) } \\
\text { increased in FMT and significantly higher compared to MET } \\
\text { at days } 7 \text { and } 28 \text { ( } p<0.05 \text { ). However significantly lower in } \\
\text { both acute diarrhoea treatment groups compared to } \\
\text { controls ( } p<0.05 \text { ). } \\
\text { hiranois (a bacterial species important for conversion of } \\
\text { primary to secondary bile acids): no significant difference } \\
\text { was found between control and FMT group at day } 28 \text {. MET } \\
\text { group showed significant decrease in C. hiranois when } \\
\text { compared to control dogs at both day } 7 \text { and day } 28 \text { ( } p<0.05 \text { ). } \\
\text { 16s rRNA gene sequencing: } \\
\text { - Significant decrease in alpha diversity in MET group } \\
\text { compared to controls ( } p<0.05 \text { ). } \\
\text { Day } 28 \text { FMT group and control no significant difference in } \\
\text { microbial communities ( } p=0.06 \text { ). }\end{array}$ \\
\hline
\end{tabular}




\begin{tabular}{|c|c|}
\hline & $\begin{array}{l}\text { Day } 28 \text { MET group still had significantly different microbial } \\
\text { communities (based on weighted distances) compared to } \\
\text { controls }(p=0.001) \text {. } \\
\text { Faecal bile acid concentrations: } \\
\text { - FMT led to significant decrease in primary bile acids at day } \\
28 \text { compared to day } 0(p<0.05) \text {. These were also lower, but } \\
\text { not significantly, at day } 7 \text { in this group. } \\
\text { - MET led to significant increase in primary bile acids at day } 7 \\
\text { ( } p<0.05) \text {. } \\
\text { Untargeted faecal metabolomics: } \\
\text { FMT dogs clustered closer to controls when compared to } \\
\text { MET dogs at day } 28 \text {. }\end{array}$ \\
\hline Limitations: & $\begin{array}{l}\text { - Not randomised. } \\
\text { - } \text { interpretation bias by the assessor. } \\
\text { - Small treatment groups. } \\
\text { - Lack of placebo. Whilst a healthy control population was } \\
\text { - included a negative control population was not. } \\
\text { - } \quad \text { Referral filter bias. } \\
\text { - No faecal scores provided for healthy control population. }\end{array}$ \\
\hline
\end{tabular}

\begin{tabular}{|c|c|}
\hline \multicolumn{2}{|l|}{ Langlois et al. (2020) } \\
\hline Population: & $\begin{array}{l}\text { Client owned dogs presenting to a University Veterinary Centre } \\
\text { (Michigan, USA) for acute diarrhoea with or without vomiting. } \\
\text { Inclusion criteria: age }>6 \text { months, BWT between } 4 \text { and } 50 \mathrm{~kg} \text {; active } \\
\text { diarrhoea < } 7 \text { days; up to date with core vaccinations. } \\
\text { Exclusion criteria: dogs receiving probiotics, antibiotics or anti- } \\
\text { inflammatory treatments in the preceding } 30 \text { days; pregnant or } \\
\text { nursing dogs; moderate to severe abdominal pain, complete } \\
\text { anorexia; moderate to severe dehydration (>8\%). } \\
\text { Laboratory evaluation: Dogs were included providing they did not } \\
\text { have evidence of gastrointestinal parasitism, Giardia spp. infection } \\
\text { or parvoviral enteritis. }\end{array}$ \\
\hline Sample size: & $\begin{array}{l}48 \text { dogs initially screened for inclusion. } 14 \text { excluded from the study. } \\
\text { Total of } 31 \text { dogs met inclusion criteria and completed the study } \\
\text { according to protocol: } 14 \text { test population and } 17 \text { controls. }\end{array}$ \\
\hline Intervention details: & $\begin{array}{l}\text { Dogs randomly allocated to either placebo } \mathrm{n}=17 \text { (capsule } \\
\text { containing only microcrystalline cellulose) or metronidazole group } \mathrm{n} \\
=14 \text { ( } 10-15 \mathrm{mg} / \mathrm{kg} \text { PO). } \\
\text { Either intervention given q12 hour for } 7 \text { days. } \\
\text { Owners also requested to withhold food for initial } 12 \text { hours after } \\
\text { enrolment and gradually resume feeding of normal diet over } \\
\text { subsequent } 12-24 \text { hours. } \\
\text { Dogs that had vomiting also received a single dose of maropitant } \\
\text { (Cerenia }{ }^{\circledR}, \text { Zoetis) } 1 \mathrm{mg} / \mathrm{kg} \text { SQ. } \\
\text { Administration of crystalloid fluids was also permitted. } \\
\text { The use of antacids, antidiarrhoeals or any newly prescribed } \\
\text { medications was not permitted for the duration of the study unless }\end{array}$ \\
\hline
\end{tabular}




\begin{tabular}{|c|c|}
\hline & $\begin{array}{l}\text { the patient clinically deteriorated; these cases were subsequently } \\
\text { excluded. } \\
\text { Dogs were returned for repeat evaluation and faecal diagnostic } \\
\text { testing on day } 7 \text {. The study was concluded in all test and control } \\
\text { dogs in which diarrhoea had resolved. Control dogs that still had } \\
\text { ongoing diarrhoea then received } 7 \text { days of metronidazole and came } \\
\text { back for final evaluation and faecal testing on day } 14 \text {. }\end{array}$ \\
\hline Study design: & $\begin{array}{l}\text { Prospective, randomised, double blinded placebo-controlled } \\
\text { treatment trial. }\end{array}$ \\
\hline Outcome studied: & $\begin{array}{l}\text { Faecal scoring logs kept by the owner (aided by the Bristol Stool } \\
\text { Chart). } \\
\text { - Timing and score of each defaecation measured, including } \\
\text { pretreatment baseline assessment. }\end{array}$ \\
\hline $\begin{array}{l}\text { Main findings: } \\
\text { (relevant to PICO question): }\end{array}$ & $\begin{array}{l}\text { Population age: } \\
\text { - Test group median age: } 4.1 \pm 3.4 \text { years. } \\
\text { - Control group median age: } 4.9 \pm 3.6 \text { years. } \\
\text { Treatment effects: } \\
\text { - Time until resolution of diarrhoea significantly associated } \\
\text { with treatment group in multivariable analysis. } \\
\quad \quad \quad \text { Time to resolution of clinical signs } 1.5 \text { day shorter in } \\
\text { metronidazole group }(p=0.04) \text {. } \\
\text { - } 29 / 31 \text { dogs had resolution of clinical signs in }<7 \text { days } \\
\text { irrespective of treatment group. } \\
\quad 13 / 14 \text { dogs in metronidazole treatment group } \\
\quad \text { duration of signs was }<4 \text { days. } \\
\text { - } 10 / 17 \text { control dogs duration of signs was }<4 \text { days; } 15 / 17 \\
\text { control dogs duration of signs was }<7 \text { days. } \\
\text { Other treatment interventions: } \\
\text { - Eight dogs in the treatment group and seven control dogs } \\
\text { received intravenous fluid therapy (IVFT) (duration }</=1 \\
\text { day). } \\
\text { Six dogs in the treatment group and six control dogs } \\
\text { received maropitant. }\end{array}$ \\
\hline Limitations: & $\begin{array}{l}\text { - Unvalidated method of stool consistency monitoring as a } \\
\text { human based chart rather than a veterinary one. } \\
\text { - Referral filter bias. }\end{array}$ \\
\hline
\end{tabular}

\section{Appraisal, application and reflection}

The available evidence is split between two randomised prospective double blinded clinical trials (Shmalberg et al., 2019; and Langlois et al., 2020), a prospective treatment trial without blinding or randomisation (Chaitman et al., 2020) and a retrospective study (Singleton et al., 2019). The retrospective study ranks low on the hierarchy of evidence and so meaningful clinical conclusions are challenging. However, the remaining studies (Shmalberg et al., 2019; Langloise et al., 2020; and Chaitman et al., 2020) are prospective, with two being randomised, double blinded, controlled trials, therefore ranking them at the highest possible level in terms of hierarchy of evidence for individual clinical studies (excluding metanalysis or systematic review). However, both of these studies are limited by small sample sizes albeit with one basing sample size on prestudy power calculation. Whilst direct comparisons between the studies cannot be made given the different treatment variables there is approximate consistency in the outcome variable assessed (time to resolution of normal faecal consistency) in all papers bar the Singleton et al. (2019) paper which assumed resolution of 
clinical signs if the patient does not represent to the clinic for GI signs within 30 days. However, there is no standardisation in the assessment of this outcome which, given its subjective nature, does lend towards observer and assessment bias. Especially given that in the three studies that utilised a faecal consistency chart (Langlois et al., 2020; Shmalberg et al., 2019; and Chaitman et al., 2020), each used a different tool, which whilst similar in nature does mean that direct study end-point (normalisation of faecal consistency) comparisons must be made with caution. Furthermore, despite the availability of veterinary faecal consistency charts, the Langlois et al. (2020) paper elected to use the Bristol Stool Chart which has been validated for humans rather than animals.

The inclusion/exclusion criteria across the three prospective studies (Shmalberg et al., 2019; Langloise et al., 2020; and Chaitman et al., 2020) allow for comparable population of dogs with what can be described as uncomplicated acute canine diarrhoea (UACD), the population that the PICO question addresses. The definition of acute diarrhoea was variable amongst paper including $<2$ day duration (Singleton et al., 2019), $<7$ days duration (Langlois et al., 2020; and Shmalberg et al., 2019) and <14 days duration (Chaitman et al., 2020). The Singleton et al. (2019) paper did not outline whether cases with severe clinical signs, confounding comorbidities or chronic gastrointestinal histories were excluded/included and so the population evaluated may not be directly comparable to the population outlined in the PICO question. Three of the studies consider tertiary veterinary centres, two university based practices (Langlois et al., 2020; and Shmalberg et al., 2019) and one specialist centre (Chaitman et al., 2020) which may lead to a referral filter bias whilst the retrospective study is more likely to representative of a general practice population (Singleton et al., 2019).

The Singleton et al. (2019) study assessed the prescribing habits of UK first opinion practitioners when faced with a case of UACD in general practice and of the 2,429 cases that were including in the analysis $52.5 \%$ of those were prescribed antibiotics within 10 days of initial presentation. Of those cases metronidazole was the most commonly prescribed ( $47 \%$ of antibiotic prescribing cases). Furthermore, the study identified 1,050 cases $(35.7 \%)$ where a patient was normothermic, with mild non-haemorrhagic diarrhoea and still prescribed antibiotics. However, the multivariable analysis of the records in this paper found no positive correlation between the prescribing of pharmaceutical agents (including antibiotics) and resolution of clinical signs. Whilst the limitations of this paper, given its retrospective nature, large loss to follow-up and inconsistency in record keeping, are significant, the large population size adds strength to the clinical utility of this information. This lack of positive correlation between antibiotic use and resolution of clinical signs was mirrored in both the Shmalberg et al. (2019) and Chaitman et al. (2020) studies, neither of which found a statistically significant superior effect of metronidazole use on the resolution of diarrhoea in when compared to a probiotic and placebo or to faecal matter transplant respectively. Both the Shmalberg et al. (2019) and Chaitman et al. (2020) studies suffer from small treatment groups and the Chatiman et al. (2020) paper did not have a placebo-control for comparison, although a healthy control population was present. Whilst a significant positive association was found between metronidazole use and duration of clinical signs in the Langlois et al. (2020) paper this study is the only one available within the literature and the small treatment group size means that caution should be taken in the clinical conclusions drawn from the data.

Chaitman et al. (2020) considered both the utility of faecal matter transplant (FMT) when compared to metronidazole on time to resolution of clinical signs as well as the impact of both FMT and metronidazole on diversity of both the microbiome and metabolome of the test subjects. The study is particularly impactful given dogs treated with metronidazole still had altered microbial and metabolic profiles 4 weeks from the start of treatment when compared to those treated with FMT or healthy controls. This study would however have benefited from a placebo control group as, although a healthy control population was assessed at a single time point, the inclusion of a placebo treatment trial would have strengthened the validity of the results of this study. The clinical significance, indeed our understanding of the implications of the findings of this study are uncertain given research into the impact of the gut microbiome is still in its infancy. However, in human medicine the intestinal bile acid pathway has been identified as important in the pathophysiology of diarrhoea (Duboc et al., 2013). The Chaitman et al. (2020) study found an increase proportion of primary bile acids in the faeces of dogs with acute diarrhoea at day 0 when compared with healthy controls. Similarly, the metronidazole treated group had higher levels of primary bile acids (and lower levels of bacteria involved in 
the conversion of primary bile acids to secondary bile acids) when compared to healthy controls suggestive of ongoing alteration of intestinal function, despite normalisation of faecal consistency.

Standardisation of treatment protocols was lacking across the three prospective treatment trial papers as well as the retrospective longitudinal study. When considering the Shmalberg et al. (2019) paper there was no standardisation in regards to the administration of crystalloid fluids, fenbendazole or maropitant and no standardisation of diet - owners do not appear to have been requested to continue to feed a normal diet and so there is potential for variation from normal diet which may have a confounding effect on duration of clinical signs. The Langlois et al. (2020) paper has similar potential for confounding effects with the administration of crystalloid fluids and maropitant although additional oral medications were not prescribed to these patients. There was a lack of standardisation of treatment in the Chaitman et al. (2020) paper in regards to both maropitant use and dietary advice. Maropitant, a NK1 antagonist is a generally very well tolerated medication but diarrhoea has been described as a rare side effect in dogs (Zoetis, 2019). However, a study assessing the use of maropitant in the face of doxorubicin associated delayed vomiting found a reduction in frequency of patients developing diarrhoea, hypothesising that there may be a role of substance $\mathrm{P}$ in the development of diarrhoea - or at least diarrhoea associated with chemotherapy (Rau et al., 2010) although no further studies have evaluated this link. So, whilst it is unlikely to have a significant impact on the outcome of these studies, its potential as a confounding variable cannot be discounted. However, clinically the use of maropitant is unlikely to be detrimental in a case of acute diarrhoea and given its potent anti-emetic effects its use should not be discounted when faced of a concurrently nauseous patient. There is also considerable variation in the prescribed dose of metronidazole across the studies (Shmalberg et al., [2019] $17.8 \pm 4.6 \mathrm{mg} / \mathrm{kg}$ PO BID; Langlois et al., [2020] 10-15 mg/kg PO BID and Chaitman et al., [2020] $15 \mathrm{mg} / \mathrm{kg}$ PO BID; with no details provided of dosages in the Singleton et al. [2019] study) again limiting direct comparison of results across the studies.

Finally, although out of the scope of this Knowledge Summary, it feels prudent to touch upon the results pertaining to probiotics in these studies. The utility of probiotics was not found to be superior when compared to either placebo or metronidazole treatment in the Shmalberg et al. (2019) study however a positive correlation was found between the utility of nutraceutical products and resolution of clinical signs in the Singelton et al. (2019) paper. Within the Singelton et al. (2019) study multiple different products were included within this one variable, compared with a single formulation within the Shmalberg et al. (2019) paper which limits the direct comparison between these two studies. However, this variability in outcome appears consistent with the latest systematic review of the available literature which concludes uncertain clinical benefit to the utility of probiotics in acute gastrointestinal disease (Jensen \& Bjornvad, 2019).

Whilst the available literature is limited, at this time there is insufficient evidence to conclude a benefit to the prescribing of metronidazole in UACD in favour of supportive measures alone. There is also evidence to suggest that the use of metronidazole can have long-term detrimental implications for the gut microbiome and metabolome. Therefore, based on this current review of the available evidence, metronidazole would not be recommended as a first-line treatment in a case of UACD. There would be benefit for further studies of a higher power (prospective, randomised, blinded placebo-controlled treatment trial) with closer standardisation of protocol and larger treatment groups. Furthermore, the utility of both subjective, but validated, faecal consistency scoring and quantitative microbiome/metabolome analysis should be considered as well as multivariant analysis in an attempt to control for confounding variables to better ascertain appropriate, evidence-based treatment protocols for the management of UACD. 


\section{Methodology Section}

\begin{tabular}{|r|l|}
\hline \multicolumn{2}{|l|}{ Search Strategy } \\
$\begin{aligned} \text { Databases searched and dates } \\
\text { covered: }\end{aligned}$ & $\begin{array}{l}\text { CAB Abstracts via the Ovid platform covering 1972-2021. } \\
\text { PubMed 1980-2021 } \\
\text { Web of Science 1992-2021 }\end{array}$ \\
\hline Search terms: & $\begin{array}{l}\text { CAB Abstracts: } \\
\text { (dog or dogs or canine) AND (metronidazole) AND (diarrhoea or } \\
\text { diarrhea) }\end{array}$ \\
$\begin{array}{l}\text { PubMed: } \\
\text { (dog or dogs or canine) AND (metronidazole) and (diarrhoea OR } \\
\text { diarrhea) }\end{array}$ \\
\hline Dates searches performed: & $\begin{array}{l}\text { Web of Science: } \\
\text { ("acute diarrhoea") AND (dog) }\end{array}$ \\
\hline
\end{tabular}

\section{Exclusion / Inclusion Criteria}

Exclusion:

- Single case reports.

- Duplicate papers.

- Book chapters.

- Conference proceedings.

- Articles not published in English.

- Articles not relevant to the PICO question.

Inclusion: Any relevant primary research paper.

\begin{tabular}{|l|c|c|c|c|c|}
\hline \multicolumn{5}{|c|}{ Search Outcome } & \multicolumn{5}{|c|}{} \\
\hline Database & $\begin{array}{c}\text { Number of } \\
\text { results }\end{array}$ & $\begin{array}{c}\text { Excluded }- \\
\text { Not relevant } \\
\text { to PICO }\end{array}$ & $\begin{array}{c}\text { Single case/report/book } \\
\text { chapter/conference } \\
\text { proceeding/duplicate }\end{array}$ & $\begin{array}{c}\text { Excluded - } \\
\text { Not available } \\
\text { in English }\end{array}$ & $\begin{array}{c}\text { Total } \\
\text { relevant } \\
\text { papers }\end{array}$ \\
\hline CAB Abs & 90 & 85 & 2 & 0 & 3 \\
\hline PubMed & 47 & 44 & 0 & 0 & 3 \\
\hline Web of Science & 18 & 17 & 0 & 0 & 1 \\
\hline
\end{tabular}




\section{CONFLICT OF INTEREST}

The author declares no conflicts of interest.

\section{REFERENCES}

1. Chaitman, J., Ziese, A., Pilla, R., Minamoto, Y., Blake, A.B., Guard, B.C., Isaiah, A., Lidbury, J.A., Steiner, J.M., Unterer, S. \& Suchodolski, J.S. (2020). Faecal Microbial and Metabolic Profiles in Dogs With Acute Diarrhoea Receiving Either Faecal Microbiota Transplantation or Oral Metronidazole. Frontiers in Veterinary Science. 7(192). DOI: https://doi.org/10.3389/fvets.2020.00192

2. Duboc, H., Rajca, S., Rainteau, D., Benarous, D., Maubert, M-A., Quervain, E., Thomas, G., Barbu, V., Humbert, L., Despras, G., Bridonneau, C., Dumetz, F., Grill, J-P., Masliah, J., Beaugerie, L., Cosnes, J., Chazouillères, O., Poupon, R., Wolf, C., Mallet, J-M., Langella, P., Trugnan, G., Sokol, H. \& Seksik, P. (2013). Connecting dysbiosis, bile-acid dysmetabolism and gut inflammation in inflammatory bowel diseases. Gut. 62(4), 531-539. DOI: https://doi.org/10.1136/gutjnl-2012-302578

3. Jensen, A.P. \& Bjørnvad, C.R. (2019). Clinical effect of probiotics in prevention or treatment of gastrointestinal disease in dogs: A systematic review. Journal of Veterinary Internal Medicine. 33(5), 1849-1864. DOI: https://doi.org/10.1111/jvim.15554

4. Langlois, D., Koenigshof, A.M. \& Mani, R. (2020). Metronidazole treatment of acute diarrhoea in dogs: A randomized doubled blinded placebo-controlled clinical trial. Journal of Veterinary Internal Medicine. 34(1), 98-104. DOI: https://doi.org/10.1111/ivim.15664

5. Rau, S.E., Barber, L.G. \& Burgess, K.E. (2010). Efficacy of maropitant in the prevention of delayed vomiting associated with administration of doxorubicin to dogs. Journal of Veterinary Internal Medicine. 24(6), 1452-1457. DOI: https://doi.org/10.1111/i.1939-1676.2010.0611.x

6. Shmalberg, J., Montalbano, C., Morelli, G. \& Buckley, G.J. (2019). A Randomized Double Blinded Placebo-Controlled Clinical Trial of a Probiotic or Metronidazole for Acute Canine Diarrhea. Frontiers in Veterinary Science. 6(163). DOI: https://doi.org/10.3389/fvets.2019.00163

7. Singleton, D.A., Noble, P.J.M., Sánchez-Vizcaíno, F., Dawson, S., Pinchbeck, G.L., Williams, N.J., Radford, A.D. \& Jones, P.H. (2019). Pharmaceutical Prescription in Canine Acute Diarrhoea: A Longitudinal Electronic Health Record Analysis of First Opinion Veterinary Practices. Frontiers in Veterinary Science. 6(218). DOI: https://doi.org/10.3389/fvets.2019.00218 


\section{EVIIDEFeE

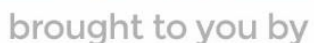 \\ RCVS KNOWLEDGE}

\section{Intellectual Property Rights}

Authors of Knowledge Summaries submitted to RCVS Knowledge for publication will retain copyright in their work, and will be required to grant RCVS Knowledge a non-exclusive license of the rights of copyright in the materials including but not limited to the right to publish, re-

publish, transmit, sell, distribute and otherwise use the materials in all languages and all media throughout the world, and to license or permit others to do so.

\section{Disclaimer}

Knowledge Summaries are a peer-reviewed article type which aims to answer a clinical question based on the best available current evidence. It does not override the responsibility

of the practitioner. Informed decisions should be made by considering such factors as individual clinical expertise and judgement along with patient's circumstances and owners' values. Knowledge Summaries are a resource to help inform and any opinions expressed within the Knowledge Summaries are the author's own and do not necessarily reflect the view of the RCVS Knowledge. Authors are responsible for the accuracy of the content. While the

Editor and Publisher believe that all content herein are in accord with current recommendations and practice at the time of publication, they accept no legal responsibility

for any errors or omissions, and make no warranty, express or implied, with respect to material contained within.

For further information please refer to our Terms of Use.

RCVS Knowledge is the independent charity associated with the Royal College of Veterinary Surgeons (RCVS). Our ambition is to become a global intermediary for evidence based veterinary knowledge by providing access to information

that is of immediate value to practicing veterinary professionals and directly contributes to evidence based clinical decision-making.

\section{https://www.veterinaryevidence.org/}

RCVS Knowledge is a registered Charity No. 230886.

Registered as a Company limited by guarantee in England and Wales No. 598443.

Registered Office: Belgravia House, 62-64 Horseferry Road, London SW1P 2AF

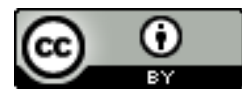

This work is licensed under a Creative Commons Attribution 4.0 International License. 